Will migrant workers rescue rural regions?

\title{
Challenges of creating stability through mobility
}

By Marit Aure, UiT The Arctic University of Norway, Department of Social Science Anniken Førde, UiT The Arctic University of Norway

Tone Magnussen, Nordland Research Institute

Corresponding author: Marit Aure, UiT the Arctic University of Norway, Department of Social Science

marit.aure@uit.no 


\title{
Will migrant workers rescue rural regions? \\ Challenges of creating stability through mobility
}

\begin{abstract}
Many rural communities experience new growth through in-migration. In Herøy, Northern Norway, this is a result of increased labour migration in the fishing industry and a comprehensive effort by the municipality to encourage migrant workers to settle there. This paper addresses the ambiguities of creating stability through mobility. Through a case study from Herøy, we explore the complex relations between migrants' mobile economic practices and social integration processes by analysing how migrants engage with Herøy's landscape in multiple manners. This landscape entails networks of people and relations, materialities, dreams and hopes. Studying engagement, in addition to contestations and intersecting trajectories, we analyse how the landscape of those on the move is interrelated with that of those "being moved through". We argue that creating stability in rural communities by encouraging migrant settlement requires going beyond economic integrationemphasising the more versatile and vulnerable processes of relating to unfamiliar places and worlds. It also requires an understanding of stability that embraces uncertainty and opens up towards various forms of belonging.
\end{abstract}

Keywords: integration, segregation, labour migration, mobility, landscape, rural, 


\section{Introduction}

"When I think of the word home, my mind is dark and empty". This is the opening line in Darta Turite's short documentary “A place” ${ }^{\prime}$. In this beautiful film from Tjøtta, an island off the North Norwegian coast, the young film student and immigrant Darta Turite reflects on what it means to feel at home in a place. The film portrays Darta's best friend Signe and her strong feelings and attachment to her home place. It also reveals Darta's own thoughts of attachment. Signe is born in Tjøtta and is closely attached to the place - to her house, the mountains and the spectacular view. "She knows what home is", Darta says. We see how Signe moves around in the landscape so dear to her, explaining how she has this incredible place to which she can always return and how that makes her strong and happy. Darta lives in the same place. However, she does not have the same attachment to this landscape. Darta comes from another place, in Latvia. She ends the film with the following lines: "In a way, I wish I could feel the same way Signe does. That home is a place. But for me, home is not filled with amazing people or beautiful nature. My home does not exist. But it doesn't mean that I'm unhappy, it just... I just don't have that feeling".

This poetic short film addresses questions of great immediate interest in our world of mobility: how do established as well as new inhabitants relate to and engage in the landscape in which they live? Darta's reflections invite us to open our perspectives on places and landscapes to a stronger sense of movement. Landscapes are in flux, with people on the move bringing in new experiences and engagements. The relationship between mobility and place attachment has been subject to considerable discussion within the field of mobility research, and it is well established that mobility is a driver of change in rural areas (Milbourne and Kitchen, 2014). The increased focus on mobility raises questions about the complex interplay between movement, fixity and place, and Milbourne and Kitchen (ibid.) call for more ethnographic research regarding rural mobility. We address this interplay using a case study 
from Herøy, in which we have followed the municipality's integration programme. Many people, such as Darta, have come from other places, particularly from Eastern Europe, but now live in rural Norway and are trying to find their place in this landscape.

The stability of rural places is often associated with senses of belonging, tradition and stasis (Milbourne and Kitchen, 2014), and according to Bell and Osti (2010), mobility is a neglected phenomenon in rural studies. However, mobility is and has always been central to the enactment of the rural (Aure, 2008; Gerrard, 2013; Milbourne and Kitchen, 2014; Munkejord, 2016; Neis et al., 2005), and rural areas are currently experiencing various types of migration, which are changing the composition of rural populations: marriage migration, asylum and refugee migration, and labour and lifestyle migration (Collantes et al., 2014; Hedberg and Haandrikman, 2014; Jentsch, 2007). The opening of the European borders led to many Eastern Europeans moving to Western Europe in search of work and new life opportunities. This represents a significant demographic trend and can be observed as a response to the population decline in rural areas, which are experiencing an ageing population, out-migration, a labour force shortage and pressure on public services (Hugo and Morén-Alegret, 2008). It is argued that migration is a pre-requisite for rural economic regeneration (Stockdale, 2006). Herøy, an archipelago located on the coast of Nordland with 1777 inhabitants, is one of these rural municipalities where a long decrease in population has changed direction. The population is now growing due to increased international labour migration in the fishing industry and a comprehensive effort by the municipality to encourage temporary labour migrants to settle and become new inhabitants. The municipality sees mobile workers as a means to create and sustain stability in the community. Whereas burgeoning research has been conducted on the political-economic processes that explain why people may move to rural areas (Dufty-Jones 2014), understanding why people stay is less researched and represents a shift towards a more contextual and relational approach to 
migration (Halfacree and Rivera, 2012). Recognizing that the fluid and the fixed are relationally interdependent (Milbourne and Kitchen, 2014), there is a need to study how emerging mobile lifestyles impact the stability of rural places (Shubin and Dickey, 2013).

Whereas the migrant workers in Herøy are actively sought after and immediately involved in the labour market, we try to understand the more versatile and vulnerable processes of relating to unfamiliar places and worlds beyond economic integration. As Bender (2001) argues, we need to ask how people on the move understand and interpret the places at which they arrive. Engagement with the landscape is an analytical lens that allows the investigation of interrelations between the social and the material as well as mobility and stability. Through this approach, we aim to contribute to the debates over integration and migration with a sensitivity to the complex connections - and disconnections - between place and belonging. The study addresses the processes involved when trying to create stability in a rural community through the settlement of migrant workers.

The article proceeds with an outline of our theoretical approach. After a section on methodology, analyses of how migrants engage with the landscape of Herøy in multiple manners follow. To illustrate the complexity of these processes, we first present two contrasting stories of in-migration to Herøy: one of a Baltic work migrant and one of a Norwegian lifestyle migrant. We then discuss how the hierarchical processes in the workplace and labour market infiltrate other arenas in Herøy. We analyse the ambiguity of creating stability through mobility by investigating how including and excluding mechanisms in social arenas are intertwined and how the robustness that is created also produces new vulnerabilities and uncertainties' that people have to live with. Through these stories, we analyse the manner in which migrant workers engage with Herøy and the challenges of social integration in a context of highly segregated working environments. We conclude with a 
discussion of the relationships between fixities and fluidities, and suggest an understanding of stability that embraces uncertainty and various forms of belonging.

\section{Theoretical approach}

Recent work regarding migration to rural areas points to how mobility influences not only the everyday lives of those on the move but also the socioeconomic situation of the host communities and vice versa (Knight et al., 2017; Milbourne and Kitchen, 2014; Shubin and Dickey, 2013). Many studies emphasise how processes of migration have become processes of settlement (Simard and Jentsch 2009, de Lima 2012, Bonifacio, 2014, Collantes et al., 2013). However, the oppositions between temporary and permanent, or mobile and settled, are challenged by emerging migrant lifestyles that create different patterns of living and working 'on the move'. As argued by Shubin and Dickey (2013: 2960), Eastern European migrants appear to 'settle within mobility'. Their mobile lifestyles are often perceived as a 'threat' to the stability of the host community (Stockdale, 2006). Place attachment and mobility are often regarded as contradictory, even though such assumptions are contested by empirical findings (Gustavson, 2001). Milbourne and Kitchen (2014) emphasise that the relationship between mobility and place attachment is not one of contradiction and mutual exclusiveness but instead connected and related to the elasticity of place. There is hence a need to challenge the assumption of the permanency of rural migration and explore how rural places become meeting places for people at different stages of complex journeys through time and space, as also argued by Milbourne (2007). To understand the following rural transformations, Jentsch (2007) and de Lima (2012) call for studies of the interaction and negotiation of migrants and their new communities. Our contribution is to study the interactions between migrants, established inhabitants and place by analysing engagement 
with landscapes of movement and stability, in addition to contestations and intersecting trajectories. Investigating engagement with landscape, we are concerned with the landscape of those on the move in addition to that of those being moved through (Bender, 2001) and how these interrelate.

Our theoretical ambition is to explore how a performative perspective on landscape can serve as a key to examine the complex relation between place and mobility. Ingold (2000) is crucial to the understanding of landscape as related to the practices of the dwellers. He defines landscape as "the world as it is known to those who dwell therein, who inhabit its places and journey along the paths connecting them" (Ingold, 2000:193). Rejecting the division between the mental and the material, he moves beyond the opposition between a naturalistic and a culturalistic view of landscape. Landscape, he says, tells - or is - the story of life and dwelling; it enfolds the life of generations who have moved around in it (Ingold, 2000). In this sense, a place owes its character to the experience and activities of all those who spend time there - also those on the move that 'journey along the paths'.

Both Bender (1998) and Massey (2006) have criticised the dwelling perspective, warning against assuming essential harmony. Bender emphasises that the manner in which people understand and engage with the worlds around them is always historically and spatially contingent and potentially conflicted (Bender, 1998, 2001). She claims that studying landscape is about the complexity of people's lives and that landscape must be studied as political, dynamic and contested, constantly open to renegotiation. Focusing on movement, migration and exile, Bender rejects the common understanding that global movements create a dislocation between people and landscape. People are never nowhere; they always relate to the landscape through which they move. Bender thus gives attention to the way that contemporary developments come together in landscapes. She discusses how and why people sharing the same landscape yet engage with it so differently, how people on the move create a 
sense of place and belonging, and how engagement with the landscape is influenced by gender, ethnicity, class, and other factors (ibid.). Landscapes thus become a means to link the local and the mobile, the stable and the temporary. We join Bender in arguing that we need to work with landscapes as polysemic, contextual, biographical and particular and study how people create sense in a world of mobility. This allows differential accounts of lives and places, imaginaries, intentions and aims. The landscapes of those on the move also affect the landscapes of the less mobile.

Massey emphasises the political aspects of place and landscape (Massey, 2005 and 2006). She argues that place and landscape must be understood as "events, as happenings, as moments that will again be dispersed" (Massey, 2006, 46). Massey conceptualises places as locations of intersecting relations and trajectories, and she highlights the "throwntogetherness" of such fluidity and interconnections (Massey, 2005). Introducing the concept of a global sense of place (Massey, 1991), Massey has been crucial of the reconceptualisation of place in which place is seen as meeting places, as open rather than bounded, as an ongoing process rather than pre-given. This approach may challenge the binaries of temporary - permanent and presence - absence, as asked for by Shubin and Dickey (2013). Heley and Jones (2012) hold that this re-conceptualisation of place has been vital to the "relational turn" in rural studies, which has made space for processes of differentiations and studies of power, among other things. Recent work about constellations of mobility (Massey 2006) has also moved beyond conventional ideas of movement - towards more relational understandings in which mobility is observed as a process producing dynamic spaces (Cresswell, 2006; Merriman, 2012; Milbourne and Kitchen, 2014). As argued by Shubin and Dickey (2013), mobility should be understood as a relational, uncertain and transformative process that opens opportunities for both individuals and communities. 
Critiques of these relational perspectives on place and landscape have claimed that in stressing relations, openness and change, a sense of groundedness has been lost (Dirlik, 2001). Massey $(2005 ; 2006)$ also discusses whether and how the increased emphasis on movement has implied a rejection of settledness, acknowledging that even in a world of flows, (temporary) stability also exists, as do territories and borders. Changes occur that lead to loss, senses of loss, new practices and recreation of borders (Aure, 2011). These changes cannot be rejected, appealing to some essential character of place. Rather, Massey (2006) argues that we must focus on the character and terms of change and the questions it raises regarding power and equality.

We argue that these perspectives on place, mobility and landscape can be fruitfully merged in studying involvement and encounters, in addition to contestations and intersecting trajectories. Performative perspectives on landscape, as presented by Ingold and others, have been criticised for a human-centred focus on the taskscapes of the everyday, which might extend into localism and lead to romanticism (Massey, 2006). In our view, focusing on landscape as performed by "those who dwell therein" does not necessarily imply coherence and harmony. Rather, it might contribute to grasping diverse ways of dwelling and journeys, complexities of encounters, the processes of differentiation and the ambivalent meanings of transforming landscapes such as Herøy.

Wylie (2003) further argues that Ingold's dwelling perspective represents an alternative post-constructionist approach in which landscape is presented as a milieu of involvement. In this perspective, landscape is neither the environment within which practice occurs nor practice itself; it is both. It is an ontological intertwining of human activity, discursive meaning and materiality (ibid.). Inspired by Ingold's landscape perspective, in addition Bender and Massey's perspectives on contestedness and throwntogetherness and a relational perspective on mobility presented by for instance Cresswell (2006), we explore the 
multiple stories of life and dwelling and people's being in the world and doing in the world in Herøy. Combining perspectives on landscape, place and mobility might help us see how places draw their significance from the relational context of people's engagement in the world. As Massey (2006) suggests, it highlights how landscape could be imagined as stories that are intertwined, continuously ongoing and unfinished - a product of the intersection of trajectories out of which the future is negotiated.

However, encounters between people do not guarantee contact and interaction (Amin, 2002), and contact is not sufficient to produce respect and acknowledgement (Valentine and MacDonald, 2004). Working together can thus result in tension, strengthening of stereotypes, and mutual multicultural understandings and misunderstandings. Contact also risks "reinforcing differences, inflaming tensions and escalating conflicts both within and between groups, especially where there are perceived inequalities between participants" (Phillips et al., 2014, 45). Former studies of migrants to coastal communities in Norway have demonstrated how migrant workers in the fish processing industry tend to be placed in restricted positions that prevent integration while making new social and spatial borders in the community (Aure, 2011). Careful studies of whether, how and what types of contact these encounters produce are therefore needed.

Places and landscapes are always in motion; they are work-in-progress (Ingold, 2000) and stories so far (Massey 2005). Landscapes are never inert, as we engage with and rework them. We understand and engage with the world in different manners, and the encounters are subjective - related to our experiences and the context. Neither place nor self stays put. Our sense of place and landscape extends from local and present encounters but is also contingent upon larger temporal and spatial fields of relationships (Bender, 2001) or trajectories and flows (Massey, 2005). Moving along familiar - or less familiar - paths, we create a sense of self and belonging; "We affect and are affected by the landscapes we move through. We 
return home, but not to the same place" (Bender, 2001, 15). In this study, we contribute to explore the complex relationship between mobility, fixity and place.

\section{Methods}

Conceiving places as complex and fluid requires reflection on how we can study them and how we contribute to the making of the places we study through our research design (Berg et al., 2013). To comprehend the ongoing negotiations of place and landscape, we need to increase our sensibility towards ambiguities and multiple meanings (ibid.). We aim to explore some of the ambiguities that emerge by examining the way that the landscape of migrants interrelates with that of established citizens in Herøy. Inspired by Law (2004), who argues that complex and untidy realities demand creative methods, we combine different approaches. Our analyses are based on a research project in which we followed a local development programme, "Integration and inclusion in Herøy", run by the Herøy municipality from 2011-2013. The purpose of the programme was to obtain a stable workforce for the growing business sector and obtain a permanent and increasing number of inhabitants ${ }^{1}$. The study was organised as process trailing and analysing activities within the programme. It is thus a case study, analysing general phenomena through particular situations, contexts, times and places. We have followed the integration programme from its start, participated in project meetings and had dialogues with the project leader.

The research team conducted two short fieldworks in Herøy in March 2012 and November 2013. The methodology applied is mainly qualitative interviews, individually and

\footnotetext{
${ }^{1}$ The project consists of a range of actions in which the aim is to ensure that migrants receive a warm welcome to Herøy and gain the necessary assistance in establishing themselves in the community. A service office for inmigrants is at the core of the development program. This office is a place to visit for all types of practical assistance concerning work permits, housing, public services and leisure activities. Training in the Norwegian language is also an important element of the project. The project is supported financially by the county administration and The Ministry of Local Government and Modernisation.
} 
in groups. We have interviewed a number of actors who are involved in and influenced by the integration project including the project leader, the project board, political and administrative leaders in the municipality, migrant workers, actors representing the employers at the main local industry (Marine Harvest), the head of the recruitment agency, health care staff, educational staff, people at the local paper and the regional museum, the leader of the volunteer centre "The Meeting Place", and other inhabitants. Altogether, we interviewed 40 inhabitants - both new/temporary and established ones. The interviews focused on Herøy as a place to live for new and established inhabitants and how it is being transformed. We have tried to capture the migrant's stories, how and why they came to Herøy, how they were met and whether and how they see their future lives here, with special emphasis on the interactions and relations between migrant workers and other inhabitants.

In addition to interviews, we attended meetings of the programme committee and arranged an open café dialogue meeting in collaboration with The Meeting Place, where people in Herøy were invited to discuss possibilities and challenges related to integration and inclusion in "the new Herøy". Though this broad approach, we have obtained a multitude of stories about current life and future hopes. By following the "Integration and inclusionprogramme" in Herøy and initiating dialogues of integration and inclusion, we also contribute to the implementation of "the new Herøy". As Law (2004) notes, methods are performative; they work to create knowledge about and in relation to the object of study. As the research project continuously emphasises processes of integration and segregation, these issues are given substantial weight in the stories we study - and produce - regarding place and landscape in Herøy.

\section{Contrasting stories of in-migration and engagement in Herøy}


Mobility and multicultural encounters have become a crucial part of the landscape of Herøy. The integration programme and the municipality's comprehensive efforts to encourage migrant workers to settle are presented as a success ${ }^{2}$ and contribute to a sense of pride. The municipality has managed to reverse depopulation, with a migrant population increasing from $2.5 \%$ in 2000 to $11 \%$ in 2013 - when the integration project was at its height (Statistics Norway and municipal numbers). Whereas migrants from Poland are generally the most numerous in Norway, most of the work migrants in Herøy come from Lithuania and Latvia. The in-migration from abroad has improved the age balance in Herøy, although the municipality still is facing an ageing population due to younger people's out-migration. However, the in-migration from abroad increases the gender imbalance, with 22 per cent more men than women among people 20-44 years old as of 2013. We find that the effort to induce work migrants to settle has many positive effects. It has contributed to secure local public services, such as the school and kindergarten. Approximately one-fifth of the children below school age are foreign born or born to two foreign parents. The new growth represents employment opportunities, creates optimism among inhabitants and has also made Herøy more attractive to Norwegians with locals moving back and other newcomers arriving (Aure et al., 2016). Whereas a combination of fish processing and small-scale farming traditionally has been the source of outcome, fish farming and processing is now the main private industry (Førde and Magnussen, 2015). Most of the labour migrants work at Marine Harvest, producing farmed salmon. A few male labour migrants that started to work there have later established private companies, whereas a few of the women work in public health care.

Before we turn to how the hierarchical processes in the workplace and labour market infiltrate other arenas in Herøy, we present two contrasting stories of arrival and settlement:

\footnotetext{
${ }^{2}$ The municipality of Herøy has been awarded with the European Council's Best Practice Award. Regeneration of European Coastal Towns (2012) and Nordland County Governors Renewal Price (2012). There have also been numerous reports in local and national media on the positive effects of settling migrant workers.
} 
Aija is an international labour migrant from Lithuania, and Ola is a fairly recent Norwegian lifestyle migrant. They are both new to Herøy, they both have families here, and they both work at the fish processing plant. These stories illustrate the complexities of mobility in rural areas and seem quite typical, as similar stories are told by many migrants in this municipality. Like many other newcomers, Aija and Ola try to make meaning of and find their place in this landscape. We explore their relationship with Herøy by analysing their stories of engagement - which are unfinished and ongoing, entailing networks of people and relations, materialities, dreams and hopes. Despite the similarities, their stories reveal considerable differences in interactions and negotiations with Herøy.

\subsection{Aija - Navigating in an unfamiliar landscape}

For two summers, Aija and their children visited her partner from Lithuania who already had found temporary work in Herøy. "The place is ok", she says, "but there was nothing to do, nowhere to go. We did not know anybody, it was so boring for the kids". At the end of the third summer, they did not return to Lithuania. Aija got a job at Marine Harvest, and the children started kindergarten and school. She felt like a stranger in Herøy, and her description of the landscape signals a sense of emptiness. In the beginning, she had no people to meet and talk to, no places to go, no activities in which to take part. The landscape did not hold much meaning to her except as a release by being away from a strenuous everyday life "back home". In that way, it was easy and comfortable yet also implied some longing for her family and friends. Her understanding of the place has changed as she has gradually become familiar with this new landscape. "Now it is OK", she says. "We will stay as long as we have work. In Lithuania, there is no good work". Already from the beginning, her mindset has been temporary and related to uncertainty, similar to findings by Shubin and Dickey (2013) in Scotland. However, Herøy became a much better place to live as soon as Aija and her partner 
had some of their family move to Herøy. The extended family spends much time together, and this bonding network (Coleman, 1994) helps Aija and her family thrive and feel attached to the place. The influx of family members represents a chain migration in which people from the same place or family follow each other in migrating to the same place (Johnson-Webb, 2003; Massey et al., 2002). It strengthens their transnational ties and their belonging to this place.

When the children started school, Aija became acquainted with some of the neighbours with children of the same age. She points up and down the street, telling about her children being involved in football and playing with other kids. The street becomes inhabited by friends and acquaintances; in network terms, creating some of the few loose bridging ties in Aija's life. There are few women among the other migrants from Lithuania, so Aija mostly socialises with the Norwegian mothers of her children's playmates and other foreign women from work. Although temporary, settling with children changed Aija's everyday engagement with Herøy; the landscape became open for social interaction, which she did not have access to as a visitor. Her dwelling and paths in the municipality, in Ingolds's (2000) terms, represents a continuum from permanence to temporary, rather than a binary opposition. These brief everyday encounters are conditioned by the proximity and ethnic diversity of the neighbourhood.

At work, Aija talks and has lunch mainly with other labour migrants, partly because this low-end job mainly attracts migrants. As shown in previous studies on the fish procession industry (Aure, 2008; Fuglerud, 1999; Gerrard, 1975; Høgmo, 1998), migrant workers such as Aija have little contact with Norwegian colleagues. This lack of contact with Norwegian colleagues at work leads to a lack of informal meetings with Norwegians outside of work, as she has no contacts to pursue. The lack of encounters in the Norwegian language also hamper socialising with Norwegians after work. Whereas Knight et al. (2017) finds that migrants 
increase their encounters with established inhabitants when changing workplaces, Herøy has a limited labour market, with few such opportunities.

The municipality of Herøy has made attempts to create new meeting places between established inhabitants and the migrants. The "in-migrants day" is one of these attempts to which Aija and her family went. They did not find their place there; "We just had some food there and nothing occurred, and I did not understand what it was all about. We just went home" she says. The "in-migrants day" was planned by voluntary organisations and the municipality leadership as a celebration and welcome of migrants and new inhabitants to the municipality. It was meant to provide an open arena and generate new encounters. To Aija, it became just another unfamiliar and inaccessible arena. This illustrates the challenges of such integration initiatives and the complex work of cultural translation involved. Despite the intentions, the event did not manage to translate to new relations for Aija or facilitate her attachment to the Herøy community.

Their future in Herøy depends on learning Norwegian, Aija explains. The work at the fish processing plant presents few opportunities to learn a language; the work is noisy, repetitive and exhausting, they wear hearing protection, and there is little time to chat. Moreover, their working language is English. Aija is attending language courses, but like many of the migrant workers at the fish plant, she finds it difficult to find time between long working hours and family obligations. The company does not offer any time off for language courses, and when asked whether she speaks any Norwegian, Aija answers "no". She explains what usually happens in social settings with Norwegians; in the beginning, everybody starts speaking English to include her - but they soon drop into Norwegian, and she feels left out. The lack of mastering the Norwegian language becomes both a practical reason for and an outcome of the lack of encounters. It prevents Aija and many of her workmates from engaging socially in the community. 
Aija has gradually become familiar with the landscape of Herøy. Still, she often feels alienated here. She longs for familiar streets. Bender (2001) links being in the world, landscape and diaspora. To Aija, the landscape she lives with constantly reminds her that she is away from her hometown. Her dream is to return "back home", but she knows this may prove difficult because "home is also changing". Aija is pragmatic and says "it's fine here", and they are actually thinking of building their own house in Herøy. This would tie the family to the place not only physically and material but also symbolically. Established people in Herøy discuss how buying a house signals an attachment and economic investment in Herøy and is seen as a proof of engagement, similar to other findings in other studies in rural Norway (Søholt et al. 2012, Aure 2008). Aija is nevertheless well aware that selling a house in Herøy may prove difficult and that investing in their own house may prevent them from moving away if there is no more work available. As noted by Rye (2008), encouraging work migrants to settle might act as a "trap". Finding her place in Herøy involves attachment as well as detachment, and creating attachment to Herøy also implies vulnerability.

\subsection{Ola-Embraced in the rural idyll}

Ola and his family moved to Herøy a few years ago. He and his wife were recruited to two good job positions: "We turned down a few other jobs elsewhere because we wanted to move here, to this type of community". They had never been to Herøy before but were searching for a small, coastal community and a particular way of life, aligning with processes of counter urbanisations (Milbourne and Kitchen 2014). He lists a number of qualities in Herøy that he values: not having to lock the doors, the beauty of the place, the natural landscape, a well-run school of culture, the municipality's priority of activities for children, and a good school and kindergarten. These are in line with the values of security, beauty, and a caring and inclusive community highlighted in perceptions of a rural idyll (Cloke et al., 
2006, Haugen and Villa, 2006). It also illustrates the significance of the municipality prioritising quality welfare state services for children. Ola and his wife were born and bred in Southern Norway and have chosen to settle in Northern Norway. Herøy meets many of their ideals regarding a good life in their current life phase - which also involves a kind of temporality. Suitable jobs made their settlement possible and connect them to Herøy, but their dreams and expectations of the rural idyll make Herøy a place of choice where they wish to belong.

Ola describes his family's encounters with Herøy as friendly and welcoming. Before they moved, Ola received a call from the principal at the school asking if anyone in the family played an instrument and wanted to join the local marching band. This turned out to be one of the most important social arenas for the family: "This is what makes me like it here". Ola continues: "The day after we moved here, a neighbour showed up on the doorstep with her daughter asking if our kids would come out to play. I think they had decided to find out who we were and help us settle and thrive...". According to Ola, he and his family were considered a resource to the community even before they arrived, and this facilitated further encounters in Herøy. Many of the encounters in which Ola and his family are engaged occur at public arenas in the municipality, school-related activities and voluntary organisations where they have got new friends. In contrast, work migrants are not invited in to organisations in the same way as Ola and his family. One of the workers at Marine Harvest is a trained professional musician. After some time in Herøy, her professional skills became known, but she did not experience any invitation to join activities or any request for her professional musical skills, which the municipality otherwise lacks. In-migrants are apparently greeted differently.

Ola is a manager at Marin Harvest; thus, he works at the same place as Aija and most of the labour migrants. He had been in this job for a year when we first meet and describes a 
segregated workplace where he has little interaction with the employees. To illustrate this, he recalls trying to join the foreign employees for lunch in the cantina: "You know", he says, "If I as a leader sit down with them in the break, they get silent and I ruin their break". Unlike most of the managers, he continues to have lunch in the cantina, but he shares a table with a few of the other "office" people. Ola has work experience from a variety of jobs and says he was somewhat surprised: "This is my first proletarian experience, so to speak". Elaborating on the social structures in the company, he describes how the "permanent staff, those who have worked here for years, sit by themselves". It turns out that the permanent workers are mostly Norwegians since the labour migrants arrived at this workplace quite recently. Few encounters between Norwegians and the labour migrants occur during working hours and breaks. Ola finds that "the divisions between people here are significant. There are divisions between leadership and workers, much more than I like. There are also distinctions between the Polish people and between the Lithuanians". The physical structure of the factory in which the production space and the offices are located on different floors - offices overviewing (and controlling) the production through glass walls from above and the socially and spatially differentiated arrangement in the cantina - do not invite encounters. In addition, whereas Norwegian employees at the fish processing plant may meet with managers at other arenas in the municipality based on kinship, neighbourhood, common interests or childhood, migrants have few other roles to play out locally and thus a limited set of arenas in which to meet, processes found also in other coastal communities (Aure, 2011).

This high level of segregation represents cracks in Ola's perception of a rural idyll, and he is concerned with the work of integration. Like Aija, he sees language as the main challenge. "Language is necessary for all communication, and also to be able to read between the lines", he says. He adds that mastering the language - or at least English - is mandatory to climb the hierarchy in the workplace. "We trust people who know the language, and we 
somehow ascribe them higher intelligence than those who don't speak English or Norwegian. Look at those middle managers we have here, so clever and capable". The two employees to whom he referred seem to be the most integrated of all the labour migrants, and they interact with the Norwegian managers, the Norwegian permanent workers and the labour migrants. The way the interplay between language skills, network and position in the labour market affects and determine integration in the community has clear similarities with studies of Polish work migrants to Wales (Knight et al., 2017). At the end of the interview, Ola adds: "I think this is a quite segregated community. This is not about fear or hostility. It's about 'not to meet'". Herøy has a continuous lack of actual encounters, even though people talk positively about each other. The next section explores how the segregation of the workplace infiltrates other arenas in Herøy.

\section{Creating stability through mobility}

In this section we discuss the ambiguity of creating stability through mobility by investigating how including and excluding mechanisms intertwines. The stories of Aija and Ola indicate that the demarcations made at the workplace also infiltrate other social arenas in Herøy. The segregation at the fish plant thus gives migrant workers such as Aija and Norwegian employers such as Ola very different opportunities to engage with the landscape of Herøy. Starting with an elaboration of workplace relations, we move on to neighbourhood and housing, local social institutions such as welfare services and leisure activities, and we end with a discussion of how local events can represent ambiguities concerning integration and inclusion.

Whereas economic aspects are often considered crucial to the integration of migrants, labour migration invites moving the discussion a step further since labour migrants are economically integrated into the labour market when they arrive. This does not necessarily 
mean that they can obtain appropriate jobs, utilise their skills and obtain promotions (Aure, 2013; Bauder, 2003). Many of the migrant workers in Herøy have a high education. However, they work as unskilled labourers in the production line of the fish processing industry with limited possibility for advancement. They thus enter into what is termed 'the migrant paradox' of highly skilled migrants taking low-skill positions led by economic motivations (Knight, 2014; Favell, 2008; Piore 1979). Similar to the Polish migrants to the UK studied by Knight (2014), the work migrants in Herøy have low employment prospects in their countries of origin. Taking part in the labour market in Herøy secures the migrants' livelihood; it gives them a stable salary and the possibility of living "a decent life" - and it positions them in the economic landscape of Herøy. As Simard and Jentsch (2009) argue, a lack of high-quality employment in rural areas is a challenge for keeping migrants in the long-term, and furthermore, the limited labour market opportunities prevent them from advancement and labour market mobility.

Although in permanent positions, the settled migrants work as unskilled workers, and this maintains the economic and social segregation between Norwegian and international workers at the processing plant. This works in concert with the established class division between managers and workers at the plant and produces further social and economic distinctions at the workplace. In addition, there is a distinction between the most permanent workers (Norwegians), who may experience upward mobility in the company, and the more recently hired but permanent workers, who are mostly from Eastern Europe and hired explicitly to do the unskilled work. This is expressed in the seating at the cantina where Norwegians and foreign workers rarely mix, the fact that they seldom interact inside or outside the workplace, and the disproportional representation of the number of foreign foremen and managers. The result resembles patterns found in the UK and the USA, where 
migrant workers from Eastern and Central Europe are increasingly relocating to small towns to take on low-skill and low-wage employment (Milbourne, 2007).

Language skills are often considered as a key element in integration processes. Studies of Polish migrants in Wales (Knight et al., 2017), shows how migrants with greater levels of competency in English are more able to bridge networks with non-Polish friends and contacts in the communities to which they have moved. In Aija`s story, the element of not being competent in Norwegian, seems to restrict her from contacts outside the network consisting of other in-migrants. As a part of the migration project in Herøy, newcomers are offered language courses at The Meeting Place "Møtestedet" adjusted to the working hours at Marine Harvest. For some of the migrants, there are still challenges: the work is physically demanding, and they feel quite exhausted after their shifts. In some families, both partners work shifts, and it is difficult to find a babysitter. A female migrant finds it difficult not being able to learn Norwegian: "It's embarrassing, having lived here for 3.5 years, and only master the Norwegian language in a basic way". Another migrant supports this, and says, "When you know the language, then integration can start". Although Marin Harvest supports the language courses, they refuse to give workers time off to attend courses during daytime.

The stories of Aija and Ola demonstrate the importance of neighbourhood relations in becoming attached to a place and creating encounters. Housing thus becomes crucial. Some of the settled migrants have bought houses. The cost of housing is high compared to the migrants' economic situation, and they have bought the cheapest houses locally available. These are located across the municipality but are rarely found in the more affluent areas, which maintains the tendency of a segregated housing pattern. Other settled migrants rent reasonably priced properties, and the migrant settlement has made the scarcity of housing opportunities in the municipality visible. As a result, the development of a housing policy has been an important part of Herøy's integration programme. New solutions to the challenges 
rural communities experience regarding housing have been tested in close cooperation with The Norwegian State Housing Bank. A new dilemma occurs as the municipality's effort to solve the situation by constructing new blockhouses seem to reinforce the segregation in many ways - it becomes a settlement of solely migrants who are divided socially and geographically from the established neighbourhoods of Norwegians.

"We will stay as long as we have work" is the way Aija phrases her long-term plans in Herøy, and this is a common statement also of other migrants. It illustrates the embedded temporality of work migration which according to Shubin and Dickey (2013) requires fluid integration, an acceptance of uncertainty and what we will call a transformative understating of place as becoming and 'throwntogether'. De Lima indicates that migrants whose primary motivation is to earn as much as possible in short time are less inclined to invest in establishing relationships; "They were likely to see the place to which they migrated as a temporary abode - "not a real home"” (de Lima, 2012, 210). The migrants we met in Herøy have flexible plans for their future, just like the Polish migrants to the UK studied by Knight (2014). Knight is thus reluctant to categorize them as 'settlers', and rather see these migrants as 'intentionally unpredictable'.

Although the primary motivation for most labour migrants in Herøy is highly economically driven, some of them settle. They try to find a place in this landscape where they can carve out a good living for themselves and their families - if only for a while. This includes not only the nuclear family but also parents, siblings and cousins. While Ola explains how he and his family felt embraced by local social institutions and people from their first arrival at Herøy, foreign migrants such as Aija strive to navigate and find their place in this landscape. However, through the occupations of everyday life, especially children's activities, her family became involved in the social life of the neighbourhood little by little. As demonstrated by Knight et al. (2017), social networks work as both catalysts and barriers for 
cultural integration. The welfare services and leisure activities for children seem to be a key to entering the social landscape on the islands for both international and Norwegian newcomers. Family networks can also serve this function. Although chain migration and networks might sustain transnational links (de Lima, 2012), they also seem to tie migrants to the place of Herøy. Many migrants claim that having a family network in Herøy with family members who actively take part in each other's everyday lives, is important for their wellbeing. Having family around seems to make them feel better, safe and somehow "at home" when moving to a new place in a different country. This resonates with studies of internal migration, demonstrating how family ties are socially, culturally and economically important for place attachment (Sørlie et al., 2012; Wiborg, 2004).

Herøy is often described as a best-case scenario in rural recruitment and integration work. Generally, little attention is paid on the positive impact of migration (Milbourne, 2007). In Herøy, they have managed to focus the public discourse on the prosperities of increased inmigration. Information - provided to both newcomers and those already settled in the community - has been an important part of the development programme "Integration and inclusion in Herøy". The local newspaper "Herøyfjerdingen" has published series of articles on migrants and their positive contributions to the community. An electronic version of the newspaper has been published in English to assure that migrants can share the information. The municipality makes numerous efforts and offers diverse services to make migrants feel welcome, and there is much to learn from it. The settling of migrants prevents a high turnover rate among the fish processing labour force, which also prevents the potential social problems that would result. The municipality has reversed a negative trend, made public and private services more robust by having more tax-payers, secured the transfer of state funds for municipal welfare services (calculated per capita), and made sure the kindergarten and school have enough children to maintain the classes. In addition, as Jentsch (2007) argues, well- 
serviced rural areas become more attractive to both migrants and those who once left them. However, the increased international migration also creates challenges for local services under constant pressure. The representatives of public services we have interviewed describe a situation in which they experience not only increasing demands but also new and diverse types of needs. The health station, which cares for pregnant women and young mothers, tells about its efforts to meet the needs of young immigrant women giving birth in a foreign country; these women do not speak Norwegian, are unfamiliar with the system and are often in vulnerable situations. These people who are new to this landscape have other necessities. Leaders in health care and educational institutions describes a situation of reduced capacity and increased needs, which they feel is neglected in the strategy work of the municipality. The increased immigration secures but also challenges local social services.

Substantial work is put into creating arenas for interaction to guide newcomers in the landscape of Herøy. Events are arranged, invitations to participate in various leisure activities are made and new arenas, such as The Meeting Place, are constructed. Based on findings from our fieldwork in Herøy where temporary and settled migrants and other inhabitants voiced a need for discussing challenges in Herøy, we invited the director at The Meeting Place to join us in organising an open 'cafe dialogue'. Together we invited new and established inhabitants and the municipal integration programme steering committee to an open meeting at The Meeting Place. Approximately 25 people attended, mainly Norwegians. During the event, we learned once again that language problems were a serious obstacle for dialogues. This became an opportunity for established inhabitants to visit The Meeting Place for the first time, but very few new inhabitants attended, and few encounters across nationalities occurred. By organising the event together with the director and in understanding with the leader of the migrant organisation, we made use of The Meeting Place in a way that did not attract the new inhabitants. The established participants and representatives from the municipality 
appreciated the opportunity to discuss challenges of 'the new Herøy', and the dialogues resulted in some concrete suggestions. But the attempt mainly illustrates the difficulties for planning for encounters on behalf of 'other' people, yet may pave the way for new encounters. However, the topology of a segregated and divided landscape is not easy to pierce, and stories of encounters and inclusion are followed by stories of non-encounters and exclusion.

\section{Conclusion}

The introductory reflections of Darta Turite's film highlight some of the difficult and urgent topics of a mobile world: how people on the move create a sense of place and belonging and how the landscape of those on the move interrelates with those being moved through. Through a case study from Herøy, we have examined how migrants enter the ongoing and unfinished stories of these changing landscapes, mainly through their position at the low end of a highly segregated workplace, and how migrants and those staying put engage with the landscapes of Herøy in different ways. Applying engagement with landscape as a lens to analyse the interrelation between mobility and place, this paper has focused on the complex processes of increasing stability by encouraging work migrants to settle. We find that work migrants are crucial in maintaining a certain stability in the rural community: securing local industry and services, such as the school, kindergartens, shops and cafés; creating optimism and making the rural community more attractive. However, the increased immigration also creates new challenges and vulnerabilities in the community. A lack of and segregated housing, increasing demands for public services and new and diverse types of needs add strain to already-stretched-thin public services. Whereas the strategy of the municipality somehow implies the work migrants "ending" and permanently or temporally ceasing their mobility, the work migrants themselves express an embedded temporality: "We 
will stay as long as we have work". On the other hand, settled migrants become more attached to the landscape by inviting family and friends to end their mobility and settle in Herøy. Although strong ties may bind them to Herøy, the lack of interaction with established inhabitants in the workplace and other arenas prevents learning the Norwegian language, which again prevents establishing new relations. Our analysis show some of the ambiguities of creating consolidation through mobile practices, and highlights the complex relations between economic and social practices and the challenges of social integration in the context of highly segregated working environments.

Mobility is central to the enactment of the rural, and coastal fishery-based communities such as Herøy have always been mobile: mobile fish stocks, long-lasting and historical global changes in export markets, and mobile fishermen and fish processing workers. Fluidity and fixity, mobility and stability are relationally interdependent. We argue in favour of opening our perspectives on place and landscape to a stronger sense of movement. Acknowledging that places and landscape are dynamic and mobile, pertinent and rigid at the same time, configured in power (geometries) and time-space, we argue that studying engagement of landscapes allows for analysing the complex relationship between stability and movement, or fixity and fluidity. Through new compositions and throwntogetherness, the landscape of Herøy is constantly reworked, negotiated, changed and thereby maintained. The emerging impact of work migration on the stability of the place acts in a complex manner, creating robustness as well as vulnerability. Our study demonstrates how class, nationality, language skills, company hierarchy, time of hire and type of employment contract are intertwined and form the topology of the economic and social landscape of this rural community, which maintains segregation and prevents interactions across ethnicities. However, new trajectories in everyday life and through children's activities, municipal efforts and neighbourhood encounters, and focus on the positive outcome 
of settled migrants, represent opportunities for interaction, engagement and attachment.

Creating such new trajectories requires going beyond economic integration and emphasising the versatile and vulnerable processes of relating to the unfamiliar.

\section{Acknowledgements}

We are grateful for an invitation to do this research and incredible support from the municipality of Herøy and for constructive comments from participants XXXXX. We also thank the reviewers for useful comments and XX for thorough comments on an earlier draft.

\section{Funding}

The project has received funding from Nordland county administration and The Norwegian Ministry of Local Government and Modernisation (Bolyst-program). Funding for proofreading was obtained from the research group $\mathrm{XXX}$ 


\section{References}

Amin, A., 2002. Ethnicity and the multicultural city: living with diversity. Environment and Planning A 34, pp. 959-980.

Aure, M., 2011. Borders of understanding: Re-making frontiers in the Russian-Norwegian contact zone. Ethnopolitics 10, pp. 171-186.

Aure, M., 2013. Highly skilled dependent migrants entering the labour market: gender and place in skill transfer. Geoforum 45, pp. 275-284.

Aure, M., Førde, A. and Magnussen, T., 2016. Lokalsamfunnet som integreringsarena [The local community as arena for integration]. In: Villa, M. and Haugen, M., Editors: Lokalsamfunn. Cappelen Damm, Oslo.

Aure, M., 2008. Arbeidsmigrasjon Fra Teriberka Til Båtsfjord 1999-2002. Det samfunnsvitenskapelige fakultet, Institutt for planlegging og lokalsamfunnsforskning: 252 s. Universitetet i Tromsø, Tromsø.

Bauder, H., 2003. "Brain Abuse", or the devaluation of immigrant labour in Canada. Antipode 35, pp. 699-717. doi:10.1046/j.1467-8330.2003.00346.x.

Bell, M.M. and Osti, G., 2010. Mobilities and ruralities: an introduction. Sociologia Ruralis 50, pp. 199-204.

Bender, B., 2001. Introduction. In: Bender, B. and Vine, M., Editors. Contested Landscapes: Movement, Exile and Place, Berg, Oxford, UK.

Bender, B, 1998. Stonehenge: Making Space, Bloomsbury Academic, London.

Berg, N.G., Dale, B., Førde, A. and Kramvig, B., 2013. Introduksjon: Metodologiske utfordringer i stedsanalyser. In: Førde, A. et al., (Eds). Å Finne sted. Metodologiske perspektiver i stedsanalyser. Akademika, Oslo.

Bonifacio, G. T., 2014. Introduction. In: Bonifacio, G. T., (E). Gender and Rural Migration: Realities, Conflict and Change, Vol. 38, Routledge, New York. 
Cloke, P., Marsden, T. and Mooney, P. Eds., 2006. Handbook of Rural Studies, Sage, London.

Cresswell, T., 2006. On the Move: Mobility in the Modern Western World. Routledge, London.

Collantes, F., Pinilla, V., Sáez, L.A. and Silvestre, J., 2014. Reducing depopulation in rural Spain: the impact of immigration. Population, Space and Place 20, pp. 606-621.

Coleman, J. C., 1994. Foundations of Social Theory. Harvard University Press, Cambridge MA.

de Lima, P., 2012. Boundary crossings: migration, belonging/‘un-belonging’in rural Scotland. In Translocal Ruralism, Springer Netherlands, Dordrecht, pp. 203-217.

Dirlik, A., 2001. Place-based imagination: globalism and the politics of place. In: Prazniak, R. and Dirlik, A., Editors. Places and Politics in the Age of Globalization. Rowman and Littlefield Publishing Group, Lanham, pp.15-51.

Dufty-Jones, R., 2014. Rural economies in the 'age of migration': perspectives from OECD countries. Geography Compass 8, pp. 368-380.

Favell, A., 2008. The New Face of East-West Migration in Europe. Journal of Ethnic and Migration Studies 34, pp. 701-716.

Førde, A. and Magnussen, T., 2015. Invaded by weeds. Contested landscape stories.

Geografiska Annaler. Series B Human Geography 92, pp. 183-119.

Fuglerud, Ø., 1999. Life on the Outside: the Tamil Diaspora and Long-Distance Nationalism. Pluto Press, UK.

Gerrard, S., 1975. Arbeidsliv og lokalsamfunn. Magistergradsavhandling. Tromsø: Institutt for samfunnsvitenskap. Universitetet i Tromsø. 
Gerrard, S., 2013. Mobilities, materialities, and masculinities: interconnected mobility practices in Norwegian coastal fisheries. Norsk Geografisk Tidsskrift - Norwegian Journal of Geography 67, pp. 312-319.

Gustafson, P., 2001. Roots and routes: exploring the relationship between place attachment and mobility. Environment and Behavior 33, pp. 667-686. doi:10.1177/00139160121973188.

Halfacree, K.H. and Rivera, M.J., 2012. Moving to the countryside ... and staying: lives beyond representations. Sociologia Ruralis 52, pp. 92-114.

Haugen, M.S. and Villa, M., 2006. Rural Idylls or Boring Places? In B.B. Bock and S. Shortall, Red, Rural Gender Relations: Issues and Case Studies. CABI Publishing, Oxfordshire, pp. 181-195.

Hedberg, C. and Haandrikman, K., 2014. Repopulation of the Swedish countryside: globalisation by international migration. Journal of Rural Studies 34, pp. 128-138.

Heley, J., \& Jones, L., 2012. Relational rurals: Some thoughts on relating things and theory in rural studies. Journal of Rural Studies 28, pp. 208-217.

Høgmo, A., 1998. Fremmed i det Norske hus: Innvandreres møte Med bygdesamfunn, småby og storby. Ad Notam, Gyldendal, Oslo.

Hugo, G. and Morén-Alegret, R., 2008. International migration to non-metropolitan areas of high income countries: editorial introduction. Population, Space and Place 14, pp. 473477.

Ingold, T., 2000. Perception of the Environment: Essays on Livelihood, Dwelling and Skill. Routledge, London.

Jentsch, B., 2007. Migration integration in rural areas: evidence from new countries of immigration. International Journal on Multicultural Societies 9, pp. 1-12. 
Johnson-Webb, K.D., 2003. Recruiting Hispanic Labor: Imigrants in Non-Traditional Areas. LFB Scholarly Publishing LLC, New York.

Knight, J., 2014. The complex employment experiences of Polish migrants un the UK labour market. Sociological Research Online 19, p. 8.

Knight, J., Thompson, A. and Lever, J., 2017. Social network evolution during long-term migration: a comparison of three case studies in the South Wales region. Social Identities, 23:1, pp. 56-70.

Law, J., 2004. After Method. Mess in Social Science Research. Routledge, New York.

Massey, D., 1991. A global sense of place. Marxism Today, June, pp. 24-29.

Massey, D., 2005. For Space. Sage, London.

Massey, D., 2006. Landscape as a provocation: reflections on moving mountains. Journal of Material Culture 11, pp. 33-48.

Massey, D., Durand, J. and Malone, N.J., 2002. Beyond Smoke and Mirrors: Mexican Immigration in an Era of Economic Integration. Russell Sage Foundation, New York. Merriman, P., 2012. Mobility, Space and Culture. Routledge, London.

Milbourne, P., 2007. Re-populating rural studies: migrations, movements and mobilities. Journal of Rural Studies 23, pp. 381-386.

Milbourne, P. and Kitchen, L., 2014. Rural mobilities: connecting movement and fixity in rural places. Journal of Rural Studies 34, pp. 326-336.

Munkejord, M. C., 2016. 'I Work With my Heart': Experiences of Migrant Care Workers in a Northern, Rural Context. Journal of Population Ageing, 1-18. DOI 10.1007/s12062$016-9157-z$

Neis, B., Binkley, M., Gerrard, S. and Maneschy, M.C., 2005. Changing tides: gender, fisheries and globalization. Fernwood Publishing, Halifax. 
Phillips, D., Athwal, B., Robinson, D. and Harrison, M., 2014. Towards intercultural engagement: building shared visions of neighbourhood and community in an era of new migration. Journal of Ethnic and Migration Studies 40, pp. $42-59$.

Piore, M. J., 1979. Birds of Passage: Migrant Labor and Industrial Societies. Cambridge University Press, Cambridge, UK.

Rye, J.F. and Andrzejewska, J., 2010. The structural disempowerment of Eastern European migrant farm workers in Norwegian agriculture. Journal of Rural Studies 26, pp. 4151.

Shubin, S. and Dickey, H. 2013. Integration and mobility of Eastern European migrants in Scotland. Environment and Planning A 45, pp. 2959-2979.

Simard, M., and Jentsch, B., 2009. Introduction: Key Issues in Contemporary Rural Immigration. In B. Jentsch and M. Simard. Eds., International Migration and Rural Areas. Cross-National Comparative Perspectives. pp. 1-16. Ashgate: Farnham, Burlington.

Stockdale, A., 2006. Migration: Pre-requisite for rural regeneration? Journal of Rural Studies 22, pp. 354-366.

Søholt, S., Aasland, A., Onsager, K. and Vestby, G.M., 2012. Derfor blir vi her - innvandrere i Distrikts-Norge, Norsk institutt for by- og regionsforskning, Oslo NIBR-Rapport 2012:5.

Sørlie, K., Aure, M., og Langset, B., 2012. Hvorfor flytte? Hvorfor bli boende? Bo- og flyttemotiver i de første årene på 2000-tallet. Oslo, NIBR-rapport, 2012: 22.

Statistics Norway. Kommunefakta. https://www.ssb.no/kommunefakta/heroy-nordland. Last Retrieved 09.01.17.

Valentine, G. and McDonald, I., 2004. Understanding prejudice: attitudes towards minorities. Stonewall. Report, www.stonewall.org.uk. 
Wiborg, A., 2004. Place, nature and migration: students' attachment to their rural home places. Sociologia Ruralis 44, pp. 416-432.

Wylie, J., 2003. Landscape, performance and dwelling: a Glastonbury case study. In: Cloke, P., Editor. Country Visions. Pearson, Essex, pp. 136-157.

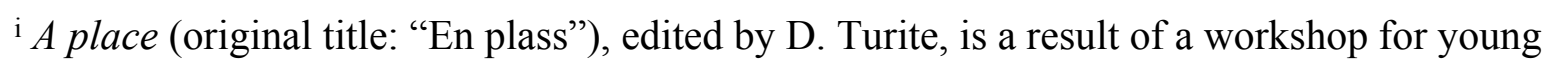
filmmakers at Filmveksthuset Tvibit, Tromsø, and a winner of the award Dokfilmfangst 2013. 